\title{
A NATUREZA DAS COISAS
}

\author{
THE NATURE OF THINGS
}

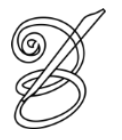

Mario Henrique DOMINGUES*

Universidade Federal do Rio de Janeiro

Rio de Janeiro, Rio de Janeiro, Brasil

\begin{abstract}
Resumo: O poema épico-didático A Natureza das Coisas (De rerum natura), de Lucrécio (Titus Lucretius Carus - séc. I a.C) é uma das grandes obras literatura universal. Fundindo poesia e filosofia, trata-se da divulgação da doutrina do filósofo grego Epicuro (300 a.C), a um tempo formado nos ensinamentos de Sócrates e reformista do atomismo de filósofos pré-socráticos, principalmente de Demócrito. No âmbito da poesia, Lucrécio influenciou grandes poetas latinos que o sucederam, tais como Virgílio, Horácio e Ovídio. O poema trata principalmente da física epicurista, em que a natureza está reduzida a átomos e ao vazio. Esta física está centrada no átomo como elemento infinitesimal da matéria, à qual estão submetidas outras categorias filosóficas como a metafísica (na aceitação da hipótese da existência dos deuses, mas também na diatribe contra a superstição) e a moral (na crítica ao amor visto como desejo meramente carnal e no elogio da amizade como "contrato social"). Tendo sido solapados pelo avanço do cristianismo, Lucrécio e Epicuro sofreram pelo menos mil anos de ostracismo. As críticas de Kant aos atomistas da antiguidade e a canonização científica da mecânica dos sólidos de Newton também influenciaram nesta quarentena do epicurismo. A partir do séc. XIX o poema de Lucrécio passou a receber a atenção de filósofos, poetas e tradutores. Na filosofia, foi estudado por Henry Bergson, Michel Serres (para quem Lucrécio seria o precursor da mecânica dos fluidos), Giles Deleuze, Clément Rosset, Phillipe Sollers e André Compte-Sponville. Na poesia francesa do XX, Paul Valéry e, sobretudo, Francis Ponge ecoam o requintado imagismo de Lucrécio. $\mathrm{O}$ fragmento ora aqui apresentado é exemplar do elogio que Deleuze fez a Epicuro e Lucrécio, por terem inaugurado o "pluralismo" na filosofia, ao apresentarem a diversidade como aspecto da natureza, distanciando-se assim das noções de unidade e conjunto (ideia de cunho religioso presente entre os filósofos pré-socráticos: para Deleuze, Epicuro e Lucrécio nos mostraram que a natureza é distributiva, e não cumulativa.
\end{abstract}

Palavras-chave: Lucrécio. Epicuro. Deleuze.

Abstract: The epic-didactic poem The Nature of Things (De rerum natura), by Lucretius (Titus Lucretius Carus $I^{\text {st }}$ century B.C.) is one of the great works of universal literature. Merging poetry and philosophy, it is a dissemination of the doctrine of the Greek philosopher Epicurus (300 B.C.), at the same time formed in the teachings of Socrates and reformist of the atomism of the pre-Socratic philosophers, mainly of Democritus. In the scope of poetry, Lucretius influenced great Latin poets who succeeded him, such as Virgil, Horace and Ovid. The poem deals mainly with Epicurean physics, in which nature is reduced to atoms and emptiness. This physics is centered on the atom as an infinitesimal element of matter, to which other philosophical categories are subjected, such as metaphysics (in accepting the hypothesis of the existence of the gods, but also in the diatribe against superstition) and morals (in criticizing love seen as merely carnal desire and the praise of friendship as a "social contract"). Undermined by the advance of Christianity, Lucretius and Epicurus underwent at least a thousand years of ostracism. Kant's criticisms of the ancient atomists and the scientific canonization of Newton's solid mechanics also influenced this Epicurean quarantine. In France, since the $19^{\text {th }}$ century, Lucretius' poem has received the attention of philosophers, poets, and translators. In philosophy, it was studied by Henry Bergson, Michel Serres (for whom Lucretius would be the precursor to fluid mechanics), Gilles Deleuze, Clément Rosset, Phillipe Sollers, and André Compte-Sponville. In the French poetry of the $20^{\text {th }}$ century, Paul Valéry and, above all, Francis Ponge echo Lucretius' refined imagery. The fragment presented here is an example of Deleuze's praise of Epicurus and Lucretius, for having inaugurated "pluralism" in philosophy, by presenting diversity as an aspect of nature, thus distancing itself from the notions of unity and set (an idea of religious nature present in the preSocratic philosophers: for Deleuze, Epicurus and Lucretius showed us that nature is distributive, not cumulative). Keywords: Epicurus. Lucretius. Deleuze. 
RECEBIDO EM: 4 de setembro de 2019

ACEITO EM: 25 de novembro de 2019

PUBLICADO EM: março 2020

Lucrécio - A natureza das coisas - Livro II, vv. 352-380

Sempre nos incensados altares dos templos

divinos os bezerros morrem imolados -

jorram do peito a quente torrente de sangue.

Aflita a mãe corre nos pastos verdes, busca

as pegadas das patas fendidas no chão,

procura em todos os lugares, como o filho

perdido achar quisesse, e espalha seus lamentos

na ramagem dos bosques, e de novo torna

ao estábulo, ferida co'a falta do filho.

360

O orvalho sobre a relva, os suaves salgueiros

116 nem os rios correntes tendo as margens cheias

distraem seu vigor, sua tensa atenção.

Seu espírito não se acalma em procurar

entre errantes bezerros nas férteis pastagens,

de tão familiar aquilo que ela busca.

Além disto, os cabritos de trêmula voz

conhecem suas mães, e os ligeiros cordeiros

o balido da ovelha: assim a natureza

pede, e cada qual busca as mamas com seu leite.

Por fim, qualquer que seja o grão de cereal,

mesmo que grãos da mesma estirpe se pareçam,

impõe-se ainda assim as formas diferentes.

Então, a variedade das conchas notamos

as praias colorindo, onde tranquilas ondas

aplainam a sedenta areia litorânea.

É preciso, portanto, que do mesmo modo,

visto que os elementos são da natureza

e não feitos por mãos sob um dado modelo,

esvoacem com formas entre si diversas. 


\section{Agradecimentos}

Agradeço a CAPES pelo apoio a minha pesquisa, a João Aroldo de Oliveira Jr, pelas sugestões e aos poetas Josely Vianna Baptista, Luis Dolhnikoff e Rodrigo Tadeu Gonçalves, que vêm acompanhando e contribuindo com minhas traduções de Lucrécio.

\section{REFERENCIA}

LUCRÈCE. De la nature. Texte établi et traduit par Alfred Ernout. Nouvelle édition revue et corrigée. Tome I. Paris: Les Belles Lettres, 1966. p. 55-56.

\footnotetext{
* Mario Henrique DOMINGUES - Graduado em Letras Português e Latim (2004) pela Universidade Federal do Paraná. Mestre em Letras - Letras Clássicas (2013) pela Universidade de São Paulo. Doutorando em Ciência da Literatura na Universidade Federal do Rio de Janeiro, bolsista Capes. Universidade Federal do Rio de Janeiro, Faculdade de Letras, Programa de Pós-graduação em Ciência da Literatura. Rio de Janeiro, Rio de Janeiro, Brasil. Currículo acadêmico: http://lattes.cnpq.br/4414994796560756

ORCID: https://orcid.org/0000-0002-7120-5295

E-mail: mariohdomingues@yahoo.com.br
} 